considerable numbers, and the eggs are agglutinated together in solid little masses, by the sticky secretion of a cephalic gland, which opens below the rostrum. The cggs are small and elliptical, and are laid to the number of many thousands. The young tick, which is usually born with but three pairs of legs, hatches out in a few days if the weather be warm, or a few weeks should it prove cold. A certain amount of moisture must be present, or the eggs are apt to dry up. These masses of eggs are laid on the ground under lierbs or grass, or on leaves. The issuing six-legged embryos larvae, like the young of other animals, are very agile, climbing on to leaves and herbage, and waiting with their front legs eagerly stretched out for the passage of the host upon which they desire to settle. Of course, not one in a thousand succeeds, and it is terrible

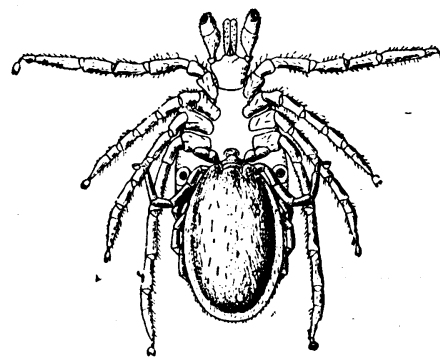

Fig. 6.-Txodes ricinis. The male genital duct before depositing its permatophore. $\times 6$. (From Brtumpt.) is inserting its rostrum in the female

to think of the amount of unsatisfied desire which must be going on in the tick world! The rest perish miserably. Those that do succeed attach themselves to the skin of the host, and thrust their rostirum and sucking tube into the hole already prepared by the cutting chelicerae. They suck the blood, and when gorged fall to the earth, or in some cases remain on the host in a state of

incrtia or apparent syncope. Soon, however, the gorged larva moults, and gives rise to the first nympl- -an eight. legged creature. This one affixes itself anew upon a liost, cither upon the same or another one, again gorges itself, and in all points resembles the adult, except from the fact that the sexual orifice has not yet appeared. After some days the first nymph moults, and this again. remains either on the host or it falls to the ground. In. some cases there are two nymph forms. But as a rule the first nympl gives rise by a second moult to the adult form, which again for the third time regains a host. The adults are now ripe for pairing, and the male having enlarged the orifice of the oviduct by inserting its rostruin, deposits therein a spermatophore or capsule full of spermatozoa. The female is often successively fertilized by several males.

In many cases the male dies after fertilization. The female swells enormously when gorged, sometimes becoming as large as a filbert, or even a small walnut. These ticks are seldom parasites of one particular host, but attack many manmals indifferently. They have many natural cnemies, amongst the most important of which are certain hemipterous insects whose female attacks the nymph of the Ixodes, and lays within the body of the tick a number of eggs which develop inside the nymph until they reach the adult stage, when they make their escape through an orifice generally at the hind end, leaving behind them the dead body of their host. Three species of sucl hemipterous insects are known, parasitic on ticlss, of these Ixodiphagus caucurtci is ubiquitous. It attacks all kinds of ticks, but especially Dermacentor venustus.

Ixodes ricinus, of a brownish colour in the male, is very common in England and, in deed, almost everywhere. The

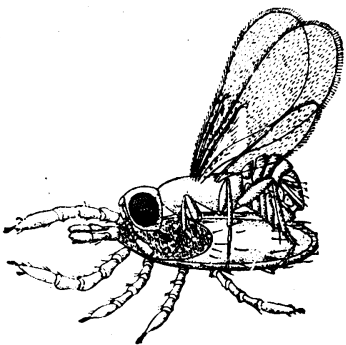
aucurtci laying esgs in the nymph of Ixodes ricinus.
Fig. 7.-Ixodiphagus

cemale is yellow and flattened, somewhat resembling a grain of rice. It is the well-known dog tick, but it attacks oxen, especially goats, deer, loorses, and man. It also attacks the grouse, and is particularly common in some parts of Great Britain. It is impossible to rid certain areas of these troublesome guests. In some cases they produce tumours and introduce bacteria, and in cattle it introduces an organism known as Babesia bovis, which is the cause of haematuria in oxen. Dermaccntor venustus transmits Rocky Mountain fever, which is common in certain parts of the States. The fever is accompanied with pains in the joints and muscles and an cruption on the surface of the skin, appearing first on the wrists and forehead, and invading in time all parts of the body, followed by a scaling of the slin cluring a period of convalescence. In Montana the mortality caused by this disease is very high, varying in different years from: 33 to 75 per cent. In Idaho it only attains a mortality of 4 per cent.

Ornithodorus moubata inoculates man with a spirochaete (Spirochaeta duttoni) which is the agent of the African tick fever or relapsing ferer. One of the curiosities about the organisms transmitted by ticks is that they live through the whole cycle of the tick's life. If threy are taken in by the larva they are only transmissible by the following larval stage. If they are taken in by the nymph they are only transmissible when again the nympl stage is met with, and the same is true of the adult. Think what such a protozoon must have seén! The fertilization of tho egg by the spermatozoon, the fusion of the nuclei, the breaking up of the egg into segments, the gradual building up of the tissues of the larva, the sudden inimsh of the host's blood when the larva is safely fixed, the moulting, the changes in the nymph, the derelopment of the genera. tive organs, the formation of the eggs! What a textbool of embryology and anatomy it could write if only it had descriptive powers! If I may paraphrase Kipling:

Think where 'e's been,

Think what 'e's seen,

Think of his future,

AND GaWd SAVE THE QUEEN!

\section{EPIDEMIC POLIOMYELITIS.}

$\mathrm{BY}$

ARTHUR A. PIM, F.R.C.S.E. BLAMIINSTER, DORSET.

Is August and September of this yoar thore was in this town and the surrounding country an outbreak of poliomyelitis, and an account of the types of the disease observed may be of interest and possibly some service to reader's of the British Medical Journal.

During the hot weat!her in August a number of children, whose ages ranged between $1: \frac{1}{2}$ and 16 years, were taken suddenly ill. The symptoms in all cases were nearly the same: the temperature was high, sometimes reaching 104, the tongue was furred, the breath offensive, and there was in all cases obstinate constipation, which was frequently only relieved by enemata. The majority of the children complained of pains in the back and limbs, and in all cases in which pain appeared carly paralysis of some muscles or groups of muscles followed in from one to seven days. In one child the paralysis affected all the muscles of the trunk and limbs, and respiration was entirely diaphragmatic.

'There werc, however, a number of other cases in which early pain was entirely absent, but the other symptoms were present which later, generally at the end of seven to ten days, sometimes after a clay or two of apparently com. plete recovery, developed acute sciatica; in no case was the sciatica accompanied or followed by paralysis of any muscle. There were also a certain number of other children who exhibited the early symptoms - of rise of temperature, furred tongue, and constipation - who recovered completely without any after-effects.

In only one case did I note the preparalytic twitchings regarded by Colliver of Los Angeles as pathognomonic of the disease. A period of incubation has, I believe, never yet been determined for poliomyelitis, but it is suggestive that two cliildren who developed the disease after leaving the torvn did so on the eighth day after departure.

The cases were widely scattered, and although in two instances more than one child was attacked in one house, the development of the disease was practically simultaneous. The distribution of poliomyelitis by flies and dust has been suggested, but a very striking fact was that in the poorest and dirtiest street of the town no case appeared. In one case the evidence in farour of infection having been conveyed by an earth closet used by a clild, who developed the disease, was considerable.

Dr. Macclaren, one of the medical officers for the county, has drawn my attention to the probability of the 
infection having been conveyed by four parents, who worked togcther in the same shop, to a child of each living in cutirely separate parts of the town. The fact that this shop was a butcher's might suggest a field for investigation.

The treatment aclopted was evacuation of the bowels followed by large closes of salol, and spraying the mouth, nose, and throat, not only of the patient, but of all contacts, with solutions of hydrargyri peroxidi or potassium permanganate.

\section{EIGHTY-SECOND ANNLAL MEETING} OF THE

\section{程ritisly eftediral Assoriation.}

Held in Aberdeen on July 29th, 30th, and 31st.

PROCEEDINGS OF SECTIONS.

\section{SECTION OF SURGERY.}

J. Scotr Riddell, M.V.O., M.B., C.M., President.

\section{THE TREATMEN'T OF CERTAIN CASES OF APPENDIX ABSCESS.}

By C. Max Page, M.S., F.R.C.S.

If one reviews the roluminous current literature on the treatment of acute appendicitis it is noteworthy that the opinion of the majority of observers on the surgical treat. ment in the early days of an attack is practically the same, whereas the rules laid down for the treatment of localized acute appendicitis (including abscess) are very varied, not only in relation to the proper time for operation, but as to its techniqut.

Statistical reports support the common conviction that surgical interference at any time in the first forty-eight hours of an acute attack is the right line to adopt. The same view is talken if, at a late stage of the disease, a case presents signs of definitely spreading or gencral peritonitis, but until every practitioner and patient is convinced of the soundness of immediate operation, cases continue to come under the care of a surgeon for the first time after the third day of the disease; and it is in relation to the treatment of some types of this class of case that I wish to make certain criticisms of the commonly adopted treat. ment.

At St. Thomas's Hospital, from the reports of which institution I propose to draw most of my figures, it has in recent years bcen customary to operate on cases of localized appendicitis at any stage of the disease, when the presence of an inflammatory mass and the lerel of the temperature suggest the possibility of suppuration; it will be admitted that it is impossible to say definitely from clinical and blood examination whether a case of acute localized appendicitis of from five to six days' standing will resolve or lead to abscess formation, or even whether there is pus present in the centre of an inflammatory mass or not. The appendix is removed if this is possible withont too great disturbance of the surrounding structures, and if pus is found the cavity is drained. If the inflammatory mass had involved the anterior parietal peritonem the results are good and complications seldom ensue. If howerer the general peritoneal cavity was not shut off, and the same line of treatment be carried out, a spreading peritonitis from the disturbed area is liable to ensue. The end result in such instances may occasionally be cleatl from peritonitis, more often it entails a prolonged convalescence with the possibility of residual abscess formation.

The likelihood of such a complication arising from operations involving the transperitoneal opening up of an infective focus is well recognized, and in order to avoid it different procedures are adrocated. The two commonest are :

1. That practised at St. Thomas's Hospital and advised by Murphy and others-namely, after opening the abdomen, to carefully pack off the surrounding peritoneal cavity with gauze plugs, deal with the infective focus and sponge out the abscess. The plugs are then removed and the abdominal wall sewn up except where a drain is left down to the infected area.

2. To lay the abdominal wall freely open, and, after opening the cavity, pack it completely with gauze and leave the abdominal wound oven. ${ }^{1}$

There are other methods in less common use, Sonnenburg, ${ }^{2}$ in his classical monograph, and sereral other German surgeons alvocate draining such cases via the pericolic cellular tissues in the loin, the peritoneum boing stripped away from the anterior and lateral walls, a drainage tube is brought out along the line of approach. Maylard ${ }^{3}$ swabs out the abscess cavity with pure carbolic acid, sprinkles it with iodoform and closes the abdoninal wound, leaving an aperture for a small draining tubs.

As already stated, the first of the above methods is the one that has been used.in general for the cases for which I propose to quote figures. Criticism of the other methols I shall not attempt here, though I shall quote figures showing the results of some of them.

I maintain that if the resistance of a patient is such that he is able to definitely localize a peritoneal infection, that paticnt should not subsequently suffer from spreading or general peritonitis. If he does, it is in nine cases out of ten due to mechanical causes, which should be avoidable.

The figures I am able to put forward show that a goo'l number of appendix abscess cases do suffer from spread of the infection after operation.

The following table shows the mortality at St. 'Thomas's Hospital from appendix abscess for the year's 1909 to 1913.

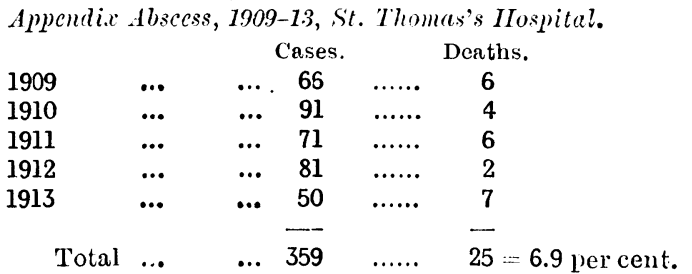

That this cieath-rate is not above the avcrage is show by the following figures taken from various sources.

\begin{tabular}{|c|c|c|c|}
\hline Source. & Cases. & Deaths. & Mortalit \\
\hline $\begin{array}{l}\text { Burgess, Britisil MEdicaL JoURNaL, } \\
\text { 1912, p. } 415\end{array}$ & $\left(\begin{array}{l}107 \\
106\end{array}\right.$ & $\begin{array}{l}2 \\
8\end{array}$ & $\begin{array}{l}1.86 \% \\
7.59 \%\end{array}$ \\
\hline $\begin{array}{l}\text { Fromme, Zeit.f. Chir., 1912, vol. cxix, } \\
\text { p. 562 } \\
\text { Krogius, Arch. f. kitin. Chir., 1911, } \\
\text { Bd.95, p. } 759 \text {. } \\
\text { MeWilliams, Med. and Surg. Rep., } \\
\text { 1912, Presby. Hosp., N.Y., p. } 445 \\
\text { Merkens, Zeit.f. Chir., } 1911 \text {... ... }\end{array}$ & $\begin{array}{r}32 \\
120 \\
60 \\
97\end{array}$ & $\begin{array}{r}1 \\
26 \\
14 \\
10\end{array}$ & $\begin{array}{l}3.1 \% \\
18.0 \% \\
23.3 \% \\
100 \%\end{array}$ \\
\hline Mutch, Guy's Hosp. Rep., 1910 ... & 183 & 18 & $10.0 \%$ \\
\hline $\begin{array}{l}\text { Richardson, British MEdical Jour- } \\
\text { NaL, } 1912 \\
\text { Vick, St. Bart's Hosp. Rep., } 1912\end{array}$ & $\begin{array}{r}299 \\
27\end{array}$ & $\begin{array}{r}12 \\
2\end{array}$ & $\begin{array}{l}4.0 \% \\
7.4 \%\end{array}$ \\
\hline
\end{tabular}

* Appendix removed.

Appondix not removed.

An analysis of the cause of death in the cases quoted from St. 'Thomas's Hospital Reports is given. The following table gives the total results:

Cause of Death in Twenty-fice Fatul Cases of Appendix Abscos, St. Thomas's IIospital, 190')-13.

General peritonitis

Intestinal obstruction

Portal pyaemia $\quad \ldots \quad$... $\quad \ldots, \quad \ldots, 3$

$\begin{array}{llllll}\text { Erysipelas... } & \ldots & \ldots & \ldots & \ldots & 1\end{array}$

In the reports of 1911-13 particulars are given of tho method of operation in the fatal cases, to the effect that of the 12 cases dying from general peritonitis in those year:s the abscess was opened across the peritoneum in 10 .

This proves, as far as figures can, that the technique I have described for the treatment of abscesses not adherent to the anterior abdominal wall is unsatisfactory. To emphasize this I may quote the figures given in the 1912 